\title{
Histidine Measurement
}

National Cancer Institute

\section{Source}

National Cancer Institute. Histidine Measurement. NCI Thesaurus. Code C122124.

The determination of the amount of histidine present in a sample. 